\title{
Delayed Neurotrophin Treatment following Deafness Rescues Spiral Ganglion Cells from Death and Promotes Regrowth of Auditory Nerve Peripheral Processes: Effects of Brain-Derived Neurotrophic Factor and Fibroblast Growth Factor
}

\author{
Josef M. Miller, ${ }^{1,2 \star}$ Colleen G. Le Prell, ${ }^{1}$ Diane M. Prieskorn, ${ }^{1}$ Noel L. Wys, \\ and Richard A. Altschuler ${ }^{1}$ \\ ${ }^{1}$ Kresge Hearing Research Institute, University of Michigan, Ann Arbor, Michigan \\ ${ }^{2}$ Center for Hearing and Communication, Karolinska Institutet, Stockholm, Sweden
}

The extent to which neurotrophic factors are able to not only rescue the auditory nerve from deafferentation-induced degeneration but also promote process regrowth is of basic and clinical interest, as regrowth may enhance the therapeutic efficacy of cochlear prostheses. The use of neurotrophic factors is also relevant to interventions to promote regrowth and repair at other sites of nerve trauma. Therefore, auditory nerve survival and peripheral process regrowth were assessed in the guinea pig cochlea following chronic infusion of BDNF $+\mathrm{FGF}_{1}$ into scala tympani, with treatment initiated 4 days, 3 weeks, or 6 weeks after deafferentation from deafening. Survival of auditory nerve somata (spiral ganglion neurons) was assessed from midmodiolar sections. Peripheral process regrowth was assessed using pan-Trk immunostaining to selectively label afferent fibers. Significantly enhanced survival was seen in each of the treatment groups compared to controls receiving artificial perilymph. A large increase in peripheral processes was found with BDNF + FGF 1 treatment after a 3-week delay compared to the artificial perilymph controls and a smaller enhancement after a 6-week delay. Neurotrophic factor treatment therefore has the potential to improve the benefits of cochlear implants by maintaining a larger excitable population of neurons and inducing neural regrowth. () 2007 Wiley-Liss, Inc.

Key words: cochlea; BDNF; FGF 1

In vivo neural deafferentation can result in cell death from neurotrophin deprivation (see Mattson and Scheff, 1994; Mattson, 1998). Withdrawal of neurotrophic factors (NTFs) leads to reactive oxygen species (ROS) production, and, ultimately, to cell death (for a review, see Kirkland and Franklin, 2003). These mecha- nisms contribute to neurodegeneration in Alzheimer's disease (de la Monte et al., 2000; Gilgun-Sherki et al., 2003; Chong et al., 2004; Summers, 2004), Parkinson's disease (Le and Frim, 2002; Tenenbaum et al., 2002; Thomas and Le, 2004), and traumatic brain injury (Lewen et al., 2000). NTF deprivation may also contribute to degeneration of the auditory nerve (AN) and loss of its somata (spiral ganglion cells, SGCs) after the onset of deafness, when sensory cells in the organ of Corti are damaged and lost. Studies have now shown that such degeneration can be reduced in mature cochlea if NTFs are provided to the spiral ganglion neurons (SGN) in vivo (Schindler et al., 1995; Ernfors et al., 1996; Staecker et al., 1996b; Miller et al., 1997; Ylikoski et al., 1998; Shoji et al., 2000; Lalwani et al., 2002; Shinohara et al., 2002; Gillespie et al., 2004; Nakaizumi et al., 2004; Yamagata et al., 2004).

The clinical consequence of $\mathrm{AN}$ degeneration is hearing loss. The cochlear neuroprosthesis restores hearing by bypassing the damaged sensory epithelium and presenting encoded electrical signals directly to the AN.

Contract grant sponsor: AMGEN Corporation; Contract grant sponsor: National Institutes of Health; Contract grant numbers: NIH-NIDCD R01 DC03820 and P30 DC005188; Contract grant sponsor: General Motors Corporation; Contract grant sponsor: The Ruth and Lynn Townsend Professor of Communication Disorders.

^Correspondence to: J. M. Miller, Kresge Hearing Research Institute, University of Michigan, 1301 East Ann Street, Ann Arbor, MI 481090506. E-mail: Josef@umich.edu

Received 22 May 2006; Revised 17 January 2007 and 12 February 2007; Accepted 12 February 2007

Published online 10 May 2007 in Wiley InterScience (www. interscience.wiley.com). DOI: 10.1002/jnr.21320 
The benefits, including speech perception without lipreading (Skinner et al., 1994, 1997; Waltzman et al., 1997; Firszt et al., 2004), depend on the density and excitability of the surviving AN (Clopton et al., 1980; Nadol et al., 1989; Incesulu and Nadol, 1998; also see Skinner et al., 2002) and electrode location. Interventions that deliver NTFs prevent AN degeneration and maintain SGC electrical excitability (Shinohara et al., 2002; Yamagata et al., 2004). Application of neural growth factor has been shown to be effective in enhancing AN survival following sensory cell loss after delays of 2 weeks (Shah et al., 1995; Gillespie et al., 2004) or even 6 weeks (Yamagata et al., 2004).

There is also benefit to survival or regrowth of AN peripheral processes. With closer proximity to AN fibers, stimulation threshold of cochlear prostheses can be reduced (also reducing electronic power requirement) and neural response dynamic range is enhanced. We therefore explored of the use of BDNF $+\mathrm{FGF}_{1}$ to both enhance AN survival and induce peripheral process regrowth in vivo. BDNF has consistently been shown to promote AN survival after deafferentation (e.g., Lefebvre et al., 1994; Hartnick et al., 1996; Malgrange et al., 1996; Staecker et al., 1996a, 1996b; Gabaizadeh et al., 1997; Miller et al., 1997; Mou et al., 1997; Gillespie et al., 2001; Nakaizumi et al., 2004). Acidic fibroblast growth factor $\left(\mathrm{FGF}_{1}\right)$ plays an important role in neurite outgrowth in the immature auditory system (Dazert et al., 1998; Hossain and Morest, 2000) during development. Both BDNF and $\mathrm{FGF}_{1}$ can induce neurite outgrowth from SGN in vitro (Hartnick et al., 1996; Malgrange et al., 1996; Dazert et al., 1998; Hossain and Morest 2000; Gillespie et al., 2001; Aletsee et al., 2003), and Altschuler et al. (1999) reported previously that although BDNF alone induced process regrowth, the richest and most extended labeling into the region of the previous organ of Corti was observed in cochlea treated with both BDNF and $\mathrm{FGF}_{1}$. FGF 1 alone was less effective, with fewer processes and less growth into the organ of Corti region. The increased effectiveness of the combination of BDNF and $\mathrm{FGF}_{1}$ was explained via BDNF functioning both as a survival factor and to induce regrowth, with $\mathrm{FGF}_{1}$ further influencing regrowth. The current data set extends the work of Altschuler et al. (1999) by precisely defining the timing within which the combination of BDNF and $\mathrm{FGF}_{1}$ is clinically useful. We examined the efficacy of BDNF $+\mathrm{FGF}_{1}$ to promote SGC survival and regrowth of the AN peripheral processes, with application beginning 4 days, 3 weeks, or 6 weeks following sensory cell loss.

\section{MATERIALS AND METHODS}

\section{Subjects}

Pigmented male and female guinea pigs (250-300 g, $n=40$; obtained from Elm Hill Breeding Laboratories, Chelmsford, MA) were used in this study. Normative histological data from an additional 8 animals, purchased from the same supplier and euthanized within an equivalent age/weight range, were drawn from an existing laboratory database (unpublished observations). The experimental protocol was reviewed and approved by the Animal Care and Use Committee at the University of Michigan. All procedures conformed to the National Institutes of Health Guidelines for the Care and Use of Laboratory Animals.

\section{Experimental Design}

Subjects were divided into six groups $(n \geq 6$ animals per group) split across two treatment conditions and three time points. Subjects in these groups were deafened via systemic aminoglycoside and diuretic treatment. A shift in threshold sensitivity, measured using the sound-evoked auditory brainstem response (ABR), of at least 60 decibels sound pressure level (dB SPL) post-aminoglycoside/diuretic treatment was required for each subject to be included in the study. Treatment conditions for deafened animals included experimental NTF groups treated with a combination of BDNF $(100 \mu \mathrm{g} / \mathrm{mL})$ and $\mathrm{FGF}_{1}(50 \mathrm{ng} / \mathrm{mL})$ diluted in a modified Konishi's solution (Konishi and Kelsey, 1973) hereafter termed artificial perilymph (AP; $118 \mathrm{mM} \mathrm{NaCl}, 30 \mathrm{mM} \mathrm{KCl}, 2.0$ $\mathrm{mM} \mathrm{MgSO} 4,1.2 \mathrm{mM} \mathrm{CaCl} 2,5.0 \mathrm{mM}$ HEPES; $\mathrm{pH}=7.40$, osmolality $=285-294 \mathrm{mOsm}$ ) with $0.1 \%$ guinea pig serum albumin; control groups were treated with AP with $0.1 \%$ guinea pig serum albumin. All substances were chronically delivered into the scala tympani via an intracochlear cannula and osmotic minipump $(0.5 \mu \mathrm{L} / \mathrm{hr}$ for 26 days). Treatment (AP or NTFs) was initiated 4 days, 3 weeks, or 6 weeks after deafening. Subjects were sacrificed and then assessed histologically following the 26-day treatment. Thus, two groups were sacrificed 30 days after deafening, two groups were sacrificed 47 days after deafening, and the last two groups were sacrificed 68 days after deafening.

\section{Auditory Physiology}

Normal hearing at the onset of the investigation was verified using sound-evoked ABR; threshold deficits (of at least $60 \mathrm{~dB}$ ) were verified 4-7 days postdeafening. Prior to the ABR procedures, animals were anesthetized with ketamine $(40 \mathrm{mg} / \mathrm{kg}$ intramuscularly) and xylazine $(10 \mathrm{mg} / \mathrm{kg}$ intramuscularly) and placed on a warm heating pad, and their ear canals were inspected using an operating microscope to assure they were free of wax and that there was no inflammation of the tympanic membrane or effusion of the middle ear. Needle electrodes were then inserted subcutaneously at the nose, at the vertex, and in the thigh. ABR thresholds were measured using brief $(160-\mu \mathrm{sec}, 50 / \mathrm{sec})$ alternating phase clicks. Tucker-Davis-Technology (TDT; Alachua, FL) software was used for signal generation (SigGen 3.2). Signals were presented using TDT System II/System III hardware, and a 200-Ohm transducer (Beyer Dynamic, Farmingdale, NY) was coupled to the external auditory meatus through a tube connected to the transducer (Beyer DT-48; Beyer Dynamic, Farmingdale, NY). Sound levels were initially set at $80 \mathrm{~dB}$ SPL for baseline tests and $120 \mathrm{~dB}$ SPL for tests conducted postdeafening. Signal calibration was based on the maximum peak-peak value of the click waveform, assuming an SPL equivalent to a continuous sinusoid with the same peak-peak 
value. Waveforms were measured using a storage oscilloscope and the SPL computed from the microphone sensitivity value. Sound intensity was decreased in 10-20 steps initially, with 5$\mathrm{dB}$ decrements used to determine threshold. Responses to 1,024 presentations were averaged for each click/level combination using a Tucker-Davis data acquisition system (BioSig 3.2). Threshold was defined as the lowest signal level at which a response could be reliably elicited based on ABR wave III or ABR wave IV. ABR wave III is the most robust component of the guinea pig $\mathrm{ABR}$ waveform and the most resistant to excitotoxic trauma (Puel et al, 1995; Le Prell et al., 2004).

\section{Deafening}

Pathology of sensory receptor cells can be induced by aminoglycoside antibiotics (Webster and Webster, 1981; Nadol et al., 1989; McFadden et al., 2004) or noise (Spoendlin, 1971; Spoendlin and Brun, 1973; Rask-Andersen et al., 2000). In these experiments, deafening was accomplished by treatment with a combination of a systemic aminoglycoside antibiotic (kanamycin) and a diuretic (ethacrynic acid). Spiral ganglion cell death begins after hair cell death; West et al. (1973) clearly demonstrated significant SGC degeneration as early as 2 weeks after kanamycin/ethacrynic acid treatment, with a much greater decrease in SGC survival by 8 weeks and then a marginal decrease continuing from 8 to 32 weeks postdeafening. Our more recent studies (Jyung et al., 1989) revealed little change in SGC density 2 weeks after kanamycin/ethacrynic acid treatment, with a rapid and significant decrease observed by 4 weeks and continuing to at least 16 weeks post-kanamycin/ethacrynic acid treatment. Presumably, the degeneration of peripheral processes began after the 2 -week assessment and prior to the 4 -week assessment. Taken together, in the 4-day postdeafened group, treatment begins in a relatively normal spiral ganglion. In contrast, in the 3week postdeafened group, treatment begins in a cell population in which degeneration has clearly begun, and in the 6 -week postdeafened group, it begins in a cell population in which degeneration is extensive ( $>40 \%$ loss).

In this investigation, all subjects were deafened with subcutaneous kanamycin $(450 \mathrm{mg} / \mathrm{kg})$ followed $2 \mathrm{hr}$ later by intravenous ethacrynic acid $(60 \mathrm{mg} / \mathrm{kg})$ as in West et al. (1973). For intravenous. injection into the jugular vein, guinea pigs were anesthetized $(40 \mathrm{mg} / \mathrm{kg}$ ketamine intramuscularly, $10 \mathrm{mg} / \mathrm{kg}$ xylazine intramuscularly) and placed on a warm heating pad. The jugular vein was surgically exposed and cannulated, and ethacrynic acid $(10 \mathrm{mg} / \mathrm{mL})$ was slowly injected over 1-2 $\mathrm{min}$. In the guinea pig, this treatment regimen resulted in loss of both inner and outer hair cells (sensory cells), except for a few scattered inner hair cells remaining in the fourth turn (Izumikawa et al., 2005). The efficacy of the deafening was initially assessed by ABR (60 dB threshold shift necessary for initial study inclusion) and subsequently confirmed by assessment of hair cell loss in plastic-embedded midmodiolar sections. After this procedure only scattered outer and inner hair cells remained and only in the most apical turn. Sections through every cochlea were checked for inner hair cell survival, and any subject showing more than a few inner hair cells surviving in the apical turn was excluded from the study. There were three animals excluded because of remaining hair cells remaining.

\section{Microcannulation of the Cochlea}

The surgical procedures used in this investigation have been described in detail previously (Brown et al., 1993; Prieskorn and Miller, 2000). In brief, guinea pigs were anesthetized $(40 \mathrm{mg} / \mathrm{kg}$ ketamine administered intramuscularly, $10 \mathrm{mg} / \mathrm{kg}$ xylazine administered intramuscularly, 1\% lidocaine delivered subcutaneously for local analgesia) and placed on a warm heating pad, and the dorsal bulla was exposed using aseptic technique. After exposing the middle ear, a cochleostomy was performed to access basal-turn scala tympani. A microcannula constructed of vinyl (size V/4; SCI Commodities, Lake Havasu, AZ) and polyimide (outer diameter $=0.16 \mathrm{~mm}$, Microlumen, Tampa, FL) tubing was then inserted and secured to the bulla and the dorsal skull. A ball of silastic $0.5 \mathrm{~mm}$ distal to the end of the cannula was seated against the outer wall of the cochlea to prevent overinsertion of the cannula as well as to seal the cochleostomy and prevent fluid leaking out of the cochlea. The bulla defect was sealed with carboxylate cement (Durelon, 3M ESPE AG, Germany), and the cannula was cemented to the dorsal skull using methyl methacrylate (Lang Dental Mfg. Co., Wheeling, IL). An osmotic minipump (Alzet model 2002; Durect Corporation, Cupertino, CA), filled with NTFs or AP, was primed in a $37^{\circ} \mathrm{C}-38^{\circ} \mathrm{C}$ water bath to allow for immediate intracochlear fluid delivery, then connected to the rostral termination of the cannula and inserted into a subcutaneous pocket between the scapulae. Cannulas were similarly filled with NTFs or AP prior to implantation. All osmotic minipumps dispensed fluids at a rate of $0.5 \mu \mathrm{L} / \mathrm{hr}$ for 14 days. To prevent a disruption in intracochlear fluid delivery, pumps were surgically removed on day 13 and replaced with new pumps such that treatment was continuous throughout the 26-day interval.

\section{Histological Examination}

Subjects were deeply anesthetized with sodium pentobarbital (FatalPlus; Vortech Pharmaceuticals, Dearborn, MI) and perfused intracardially with $0.1 \mathrm{M}$ phosphate buffer $(\mathrm{pH}=$ 7.40) followed by $4 \%$ paraformaldehyde. After decapitation, the temporal bones were removed and opened to expose the cochleas. The cochleas were dissected open and gently flushed with fixative, followed by postfixation with $4 \%$ paraformaldehyde for $2 \mathrm{hr}$. The otic capsule, lateral wall, and Reissner's and tectorial membranes were removed, and the cochlear spiral was placed in $0.3 \%$ hydrogen peroxide to remove endogenous peroxidase activity. Following several rinses in PBS, the tissues from all deafened animals were placed in phosphate-buffered saline (PBS) plus $0.1 \%$ Triton-X (Electron Microscopy Sciences, Ft. Washington, PA) and 3\% normal goat serum (Vector Laboratories, Burlingame, CA) for $1 \mathrm{hr}$. The primary antibody was the pan-Trk antibody c-Trk (Ab-1; Oncogene Research Products, Boston, MA); it was diluted 1:100, and tissues were placed in this solution for 20$24 \mathrm{hr}$ at $4^{\circ} \mathrm{C}$. Detection of the primary antibody was accomplished using an avidin-biotinylated horseradish peroxidase macromolecular complex (Avidin-Biotin Complex, Vectastain 
Elite ABC kit; Vector Laboratories, Burlingame, CA). Visualization of the antibody was done with $0.05 \% 3,3^{\prime}$-diaminobenzadine (DAB peroxidase substrate kit, Vector Laboratories, Burlingame, CA).

Tissues (including those from deafened animals and those from untreated control animals with intact hearing processed as part of the normative database) were decalcified and embedded in JB-4 Resin (a water soluble embedding medium based on glycol methacrylate plastic embedding; Electron Microscopy Sciences, Ft. Washington, PA). Midmodiolar plastic sections were cut $3-4 \mu \mathrm{m}$ thick; every third midmodiolar section was mounted on a glass slide until 15 sections had been mounted. These sections were then stained with toluidine blue (1.46 g; J. T. Baker, Phillipsburg, NY) and basic fuchsin (0.54 g; Allied Chemical, New York, NY), dissolved in 30\% ethanol $(200 \mathrm{~mL}$; PharmCo Products Inc., Brookfield, CT), and saved for SGC counts and density measures. Six additional consecutive midmodiolar sections were cut from immunolabeled cochleas and mounted on glass slides without the toluidine blue/basic fuchsin stain. These tissues were used for assessment of regrowth of peripheral processes based on pan-Trk labeling.

In a small number of additional animals $(n=3)$, tissues were not sectioned with a cryostat but were instead prepared as surface dissections. Coimmunofluorescent labeling for panTrk and the efferent-specific marker synaptophysin (IGN Pharmaceuticals, Inc.) was performed using highly specific second antibodies (Molecular Probes) with different Alexa chromophores to show the specificity of the labeling. Merged images were acquired with an Olympus FV-500 laser scanning focal microscope.

\section{Pan-Trk Antibody Selection}

Pan-Trk antibodies immunostain all members of the Trk receptor family (TrkA, TrkB, TrkC) as well as Trk protein inside prostrate epithelial cell bodies (Pflug et al., 1995). Antibodies to pan-Trk have been used to identify the cytoplasmic domain of Trk receptors on SGC explants (Mou et al., 1997) and also to label the AN peripheral processes (Altschuler et al., 1999). The antibody we selected [C-Trk $(\mathrm{Ab}-1)]$ is a polyclonal antibody raised against a peptide sequence (A L A N A P P V Y L D V L G) found in the Cterminal domain corresponding to residues 777-790 (Oncogene Research Products, catalog PC31).

\section{Pan-Trk-Positive Fiber Quantification of AN Peripheral Processes}

Pan-Trk immunostaining was evaluated in tissues from all deafened animal groups using a $100 \times$ objective. Six staining profiles were examined on six sections from each animal. Positively stained fibers were counted only if they emerged from the habenula perforata, indicating afferent fibers that had been maintained in or had regrown into the region of the basilar membrane/organ of Corti. Fiber length could not be determined; thus, quantification was limited to fiber number.

\section{Cell Density of Spiral Ganglion Cells}

Every third midmodiolar section was mounted on a glass slide until 15 sections had been mounted and a random start point generated; the six sections from that point were used to generate an "analysis length" of $72 \mu \mathrm{m}$. Six Rosenthal's canal profiles, visible on each section (two from the basal cochlea, two from the middle turn, and two from the apical turn), were assessed for each toluidine blue/basic fuchsin-stained section by an observer blind to treatment condition. Spiral ganglion cells were counted as normal if they met these criteria: (1) had a diameter of 14-22 $\mu \mathrm{m}$ and an area of 153-380 $\mu \mathrm{m}^{2}$; and (2) had a nucleus, with a diameter of $5-10 \mu \mathrm{m}$. The outline of each profile of Rosenthal's canal was traced using a computer mouse. Cell count and cell area were then used to calculate cell density. All measurements were calculated using the Metamorph Image Acquisition, Enhancement, and Analysis System (Molecular Devices Corporation, Sunnyvale, CA).

\section{Statistical Comparisons}

Spiral ganglion cell density was evaluated for each of the six cochlear-turn profiles in the midmodiolar sections from the animals tested in this investigation; these values were compared to normative data from animals that were not deafened or otherwise treated ( $n=8$, unpublished observations, laboratory normative data). Initial statistical comparisons of SGC density were for untreated animals and used one-way analysis of variance (ANOVA) based on profile number (1-6) to confirm that SGC density did not vary with profile number (i.e., cochlear place) in normal (untreated) ears. Two-way ANOVA with treatment and profile number (1-6) as factors was used for subsequent comparisons performed at each treatment delay (4 days, 3 weeks, and 6 weeks). There was no main effect for profile or interaction effects for profile (i.e., SGC density did not vary with profile number, and the statistical reliability of changes in SGC density and fiber count associated with NTF treatment did not depend on which profile was evaluated, all $P>0.1$ ). As there was no effect of profile (cochlear place), data were collapsed across profiles and additional statistical comparisons were based on data from the whole cochlea without regard to profile number.

Two-way ANOVA with treatment (AP, NTFs) and treatment delay (4 days, 3 weeks, and 6 weeks) as factors was used to determine the statistical reliability of protection induced by NTF treatment in deafened animal groups. To balance the data sets for SGC density comparisons including normal untreated ears, two procedures were used. First, oneway ANOVA was employed to compare untreated (AP) controls with (NTF) treated groups after 4-day, 3-week, and 6week delays in the AP and in the NTF groups. Second, we arbitrarily assigned time points of 4 days, 3 weeks, or 6 weeks to the baseline data such that two-way ANOVA using time point (4 days, 3 weeks, and 6 weeks) and treatment (none, AP, NTFs) was possible. The data handling procedures yielded the same pattern of results, that is, statistically reliable differences revealed with the one-way ANOVA were also revealed using the two-way ANOVA, and vice versa. Statistical comparisons of the number of pan-Trk-positive fibers included an initial two-way ANOVA with treatment and profile number (1-6) as factors, with comparisons conducted at 

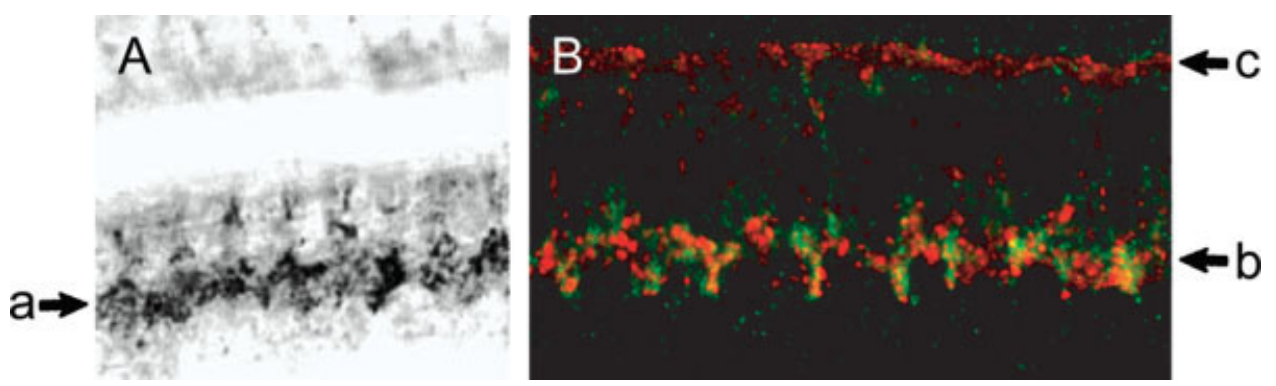

Fig. 1. A: Pan-Trk immunoperoxidase antibody labels afferent processes and synaptic terminals at the bases of inner hair cells in surface preparations of normal guinea pig cochlea. Tissue from the second turn of the cochlea is shown. B: Confocal analysis of coimmunofluorescent labeling for pan-Trk and the efferent-specific antisynapto- physin antibody shows pan-Trk labeling of afferents (green) is distinct from synaptophysin labeling of efferents (red). The small portion of "yellowish" label from the overlap of the red and green labels may indicate the regions where efferent neurons make synaptic contact with afferent neurons.

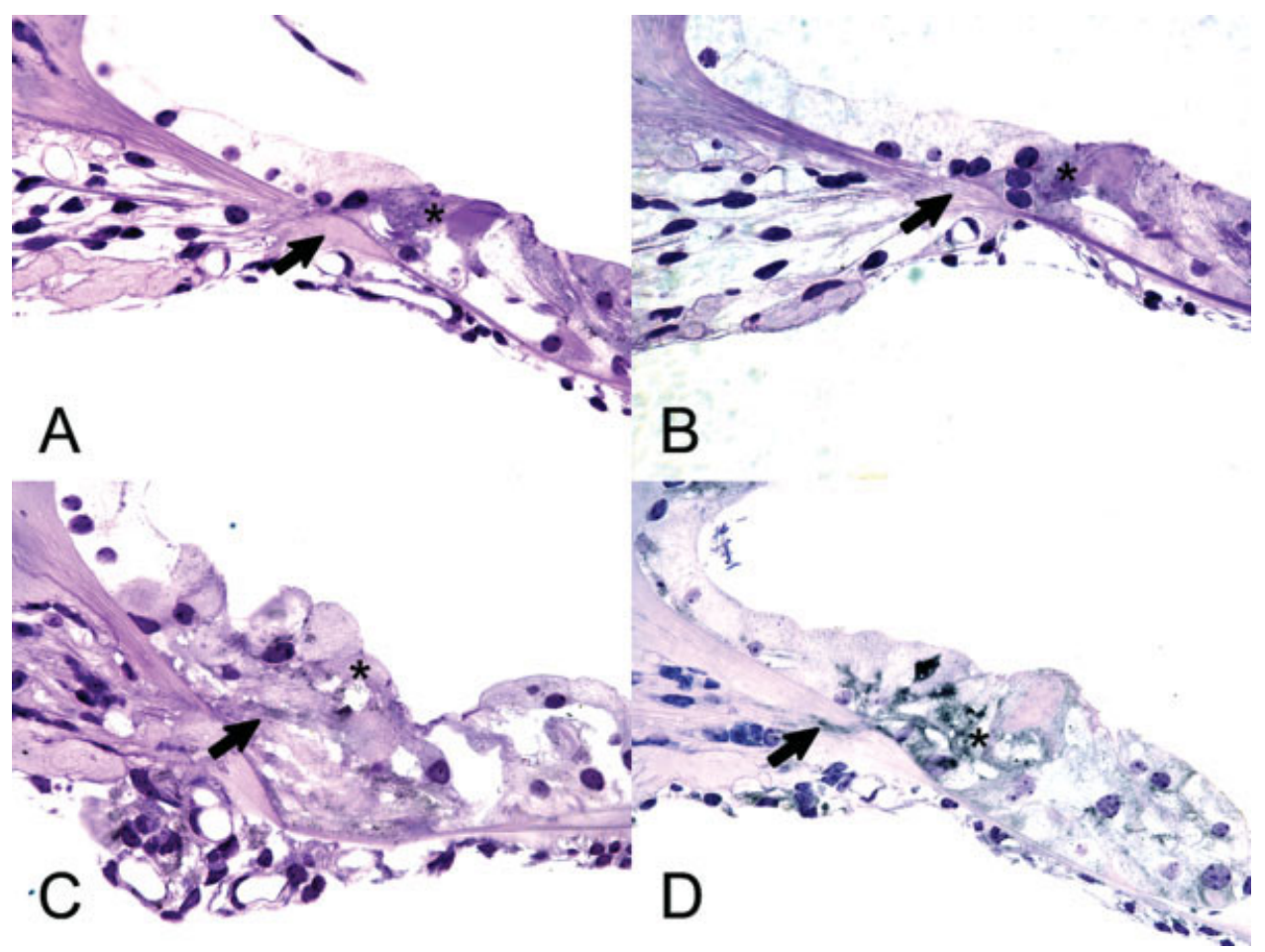

Fig. 2. Significant scar formation was evident in the region that normally has hair cells (see asterisks, A and B) in deafened control animals (A: 4 days deaf, then artificial perilymph; B: 6 weeks deaf, then artificial perilymph). No pan-Trk-immunostained processes extended out of the habenula perforata in tissues from deafened control animals (A and B; see arrows). $\mathrm{BDNF} / \mathrm{FGF}_{1}$ treatment resulted in one or more pan-Trk-im- munostained processes. Pan-Trk-immunolabeled processes can be seen extending through the habenula perforata (see arrows) and into the scar region (see asterisks) in animals that received $\mathrm{BDNF} / \mathrm{FGF}_{1}$ treatment 4 days after deafening $(\mathrm{C})$ and in animals whose treatment was delayed longer (D: 6 weeks postdeafening). each treatment delay ( 4 days, 3 weeks, and 6 weeks). There was no main effect for profile, and as above, data were collapsed across profiles, and additional statistical comparisons [two-way ANOVA with treatment (AP, NTFs) and treatment delay (4 days, 3 weeks, and 6 weeks) as factors] were based on data from the whole cochlea without regard to profile number. This analysis allowed the efficacy of the NTF treatment to be compared to AP control-treated material at each of the three postdeafening survival periods and also the influence of the percentage of surviving SGCs at the initiation of treatment on treatment efficacy to be assessed.

Normal untreated ears immunolabeled using antibodies to pan-Trk were evaluated as surface preparations; thus, there was no quantification or statistical comparison of normal and deafened ears on this measure. SigmaStat for Windows (version 2.03, SPSS., Inc., Chicago, IL) was used for all analyses. 


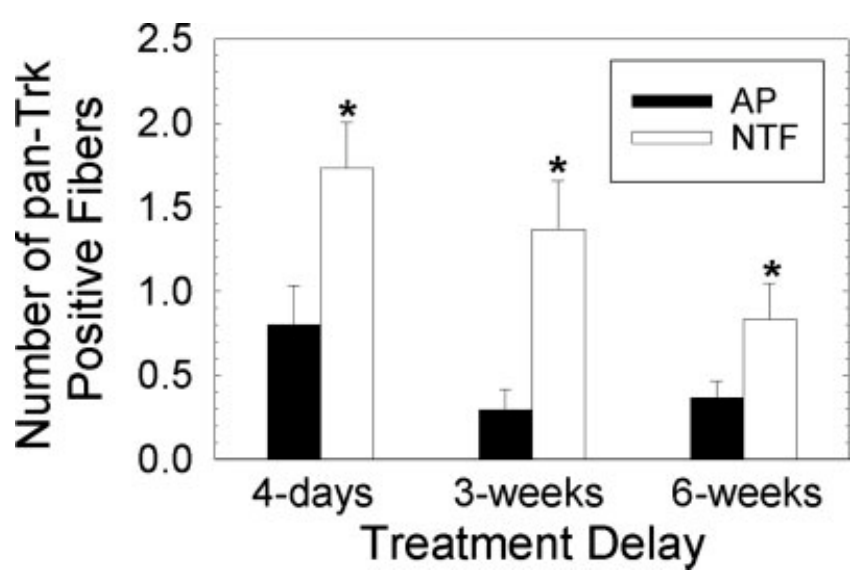

Fig. 3. Treatment with a combination of NTFs (BDNF + FGF1) increased pan-Trk-positive spiral ganglion peripheral process (fiber) count relative to the artificial perilymph (AP) control, even with delayed treatment (all data are means \pm SEs). Pan-Trk-positive fiber count did not vary with cochlear position; therefore, data from across the cochlea were collapsed. "Statistically significant differences of AP-NTF comparisons within each time point (all $P<0.005$ ). An overall effect-of-treatment delay was also observed, with a greater number of fibers counted after shorter delays. Animals in the control group, treated with AP, showed an immediate and substantial decrease in fiber count ( 4 days vs. 3 weeks, $P<0.05$ ), with no further loss associated with a 6 -week delay ( 3 weeks vs. 6 weeks, $P>$ $0.05)$. With NTF treatment, the number of fibers decreased from 4 days to 3 weeks to 6 weeks (all $P<0.05$ ).

\section{RESULTS}

\section{SGC Peripheral Processes}

Pan-Trk Selectively Labels Afferent Neurons. The appearance of pan-Trk immunoperoxidase labeling of a surface preparation is shown in Figure 1A. The labeling is of afferent processes and terminals at the bases of inner hair cells in the second turn of the cochlea from a normal hearing guinea pig. Coimmunofluorescent labeling for pan-Trk and the efferent-specific marker synaptophysin shows that pan-Trk labeling of afferents (green) is distinct from synaptophysin labeling of efferents, in red (Fig. 1B), with perhaps a little portion of "yellowish" label from the overlap where efferents make synaptic contact with afferents.

Pan-Trk-Positive Fiber Count. Pan-Trk-immunostained processes extending out of the habenula perforata were relatively rare in deafened control animals receiving AP infusion, and when observed they never extended very far past the habenula. One or more panTrk-immunostained processes were found in almost all $\mathrm{BDNF} / \mathrm{FGF}_{1}$-treated animals (see Fig. 2). Processes in animals treated with NTFs extended for variable distances into the scar region of lost hair cells. Tissues from animals that received $\mathrm{BDNF} / \mathrm{FGF}_{1}$ after the shortest period of deafness (4 days) generally contained more labeled fibers than did those receiving delayed treatment (i.e., treatment
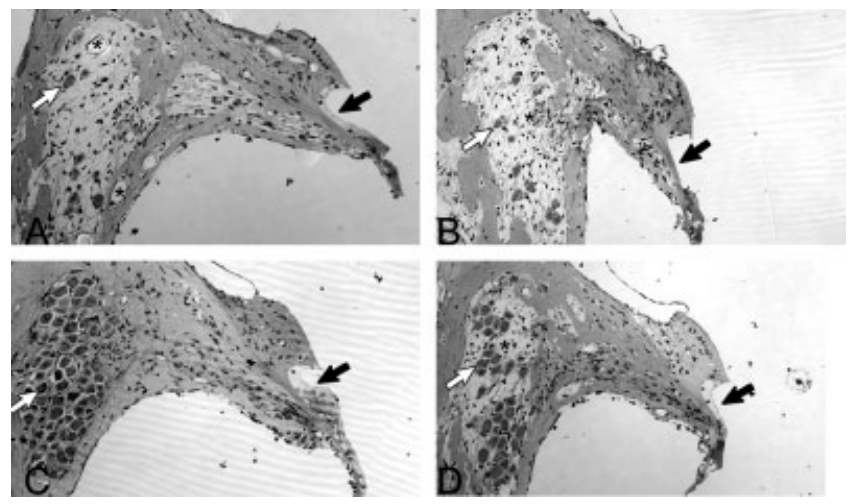

Fig. 4. Representative paramodiolar plastic sections from four conditions (groups) with profiles through Rosenthal's canal and the organ of Corti from first (basal) turn. Complete loss of hair cells occurred in all four conditions, with scar tissue replacing the lost hair cells (see solid black arrows), consistent with all groups being deafened in an equivalent fashion prior to differential treatments. There was variability in the number of remaining spiral ganglion cells among the four treatment conditions. In deafened but untreated control animals (A: 4 days deaf, then artificial perilymph; B: 6 weeks deaf, then artificial perilymph), the number of spiral ganglion cells per profile was greatly reduced. The spiral ganglion cells evident in these tissues also appeared smaller (see white arrows, A and B). In place of the missing cells, significant vacuole formation was evident (see asterisks, A and B). Treatment with neurotrophic factors increased spiral ganglion cell survival, resulting in more spiral ganglion cells remaining in the profiles through Rosenthal's canal. The spiral ganglion cells increased in number and appeared larger in animals treated with $\mathrm{BDNF} / \mathrm{FGF}_{1} 4$ days (C) and 6 weeks (D) following deafening.

initiated after 3 or 6 weeks of deafness; see Fig. 3); however, the fibers in the delayed-treatment animals often had the longest regrowth in the scar regions.

The increase in pan-Trk-positive SGC peripheral processes (fibers) in both the 4-day- (immediate) and delayed-treatment groups (i.e., Fig. 3) was statistically significant. Two-way ANOVA revealed a statistically significant $(P \leq 0.001)$ increase in peripheral processes in the NTF-treated group compared to its AP control $(F=$ 73.835, $d f=1,213 ; P<0.001)$. An overall effect of treatment delay was also observed $(F=17.564, d f=$ $2,213 ; \quad P<0.001)$, with greater numbers of fibers observed after shorter delays. Pairwise comparisons, conducted using the Tukey test, revealed that NTF treatment reliably increased the number of fibers observed over AP control material regardless of treatment delay (all $P<0.005)$. There was a reliable interaction between treatment and treatment delay $(F=3.582, d f=2,213 ; P$ $<0.05)$. Pairwise comparisons revealed that animals in the deafened control group, treated with AP, showed an immediate and substantial decrease in pan-Trk-immunolabeled fiber count ( 4 days vs. 3 weeks, $P<0.05$ ), with no further loss associated with a 6-week delay (3 weeks vs. 6 weeks, $P>0.05$ ). However, with NTF treatment, the number of fibers decreased from 4 days to 3 weeks to 6 weeks (all $P<0.05$ ). 


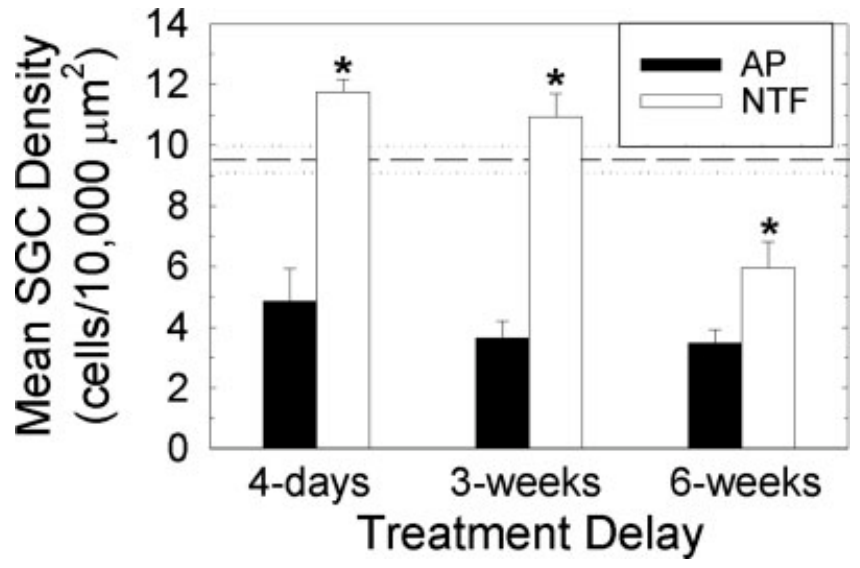

Fig. 5. Treatment with a combination of NTFs $\left(\mathrm{BDNF}+\mathrm{FGF}_{1}\right)$ increased spiral ganglion cell (SGC) density relative to artificial perilymph (AP) control, even with delayed treatment (all data are means \pm SEs). SGC density did not vary with cochlear position; therefore, data from across the cochlea were collapsed. *Statistically significant differences of AP-NTF comparisons within each time point (all $P<$ 0.001). An overall effect-of-treatment delay was also observed, with greater density of fibers observed after shorter delays. Animals in the control group, treated with AP, showed an early decrease in SGC density (4 days vs. 3 weeks, $P<0.05$ ), with no further loss associated with a 6 -week delay ( 3 weeks vs. 6 weeks, $P>0.05$ ). With NTF treatment, SGC density decreased later (4 days vs. 3 weeks, $P>$ $0.05 ; 3$ weeks vs. 6 weeks, $P<0.001)$. SGC density in all AP and NTF groups reliably differed from normative data from 8 normalhearing untreated animals drawn from an existing laboratory database (mean, dashed line; SE, dotted lines). Relative to that of normalhearing animals, SGC density was increased in the 4-day- and 3week-delayed NTF groups and was decreased in the AP groups and the 6-week-delayed NTF group (all $P<0.01$ ).

\section{Cell Density of Spiral Ganglion Cells}

Representative images of spiral ganglion cells are shown in Figure 4. Treatment with a combination of NTFs $\left(B D N F+F_{1} F_{1}\right)$ increased spiral ganglion cell density relative to AP control, even with delayed treatment (see Fig. 5). Generally, the SGCs in cochleas with greater survival also had a better appearance; they were larger, rounder, without vacuolization, and with surrounding myelin closely associated. Two-way ANOVA revealed a statistically significant $(P \leq 0.001)$ enhancement of SGC density in the NTF-treated group compared to its AP control $(F=404.669, d f=1,216 ; P<0.001)$. An overall effect of treatment delay was also observed $(F=61.491, d f$ $=2,216 ; P<0.001$ ), with greater density of fibers observed after shorter delays. Pairwise comparisons, conducted using the Tukey test, revealed that NTF treatment reliably increased SGC density regardless of treatment delay (all $P<0.001$ ). There was a reliable interaction between treatment and treatment delay $(F=32.070, d f=$ 2,216; $P<0.001)$. Moreover, pairwise comparisons revealed that animals in the deafened control group, treated with AP, showed an immediate and substantial decrease in SGC density (4 days vs. 3 weeks, $P<0.05$ ), with no further loss associated with a 6-week delay (3 weeks vs. 6 weeks, $P>0.05)$. With NTF treatment, SGC density did not decrease as treatment delay increased from 4 days to 3 weeks $(P>0.05)$; however, a decrease in SGC density observed with further delay (3 weeks vs. 6 weeks) in the NTF treatment groups was statistically reliable $(P<$ 0.001). Additional comparisons revealed that increased SGC density in 4-day- or 3-week-delayed NTF groups compared with SGC density in untreated normal ears was statistically reliable (all $P<0.01$ ); decreased SGC density in the AP groups and the 6-week-delayed NTF group compared with SGC density in untreated normal ears was also reliable (all $P<0.01$ ).

\section{DISCUSSION}

\section{Enhancement of SGC Processes, Even with Delayed Treatment}

BDNF and $\mathrm{FGF}_{1}$ reliably enhanced the number of SGC peripheral processes, with significantly greater counts of pan-Trk-positive processes emerging from the habenula perforata when treatment was initiated 4 days, 3 weeks, or 6 weeks postdeafening. Pan-Trk labeling was selective for AN processes, distinguishing AN processes from olivocochlear efferent fibers, which were not labeled by pan-Trk (i.e., Fig. 1B). We found the greatest number of pan-Trk-positive fibers with treatment delayed only 4 days following deafness. With 3 -weekdelayed treatment there was still a large increase, fivefold over the labeling seen in the AP control animals. There was a twofold increase over AP control levels in the animals with 6-week-delayed treatment with BDNF and $\mathrm{FGF}_{1}$, but the total number was greatly reduced from the 4-day and 3-week delays. This may suggest that at 6 weeks the deafferented SGCs had reduced responsiveness to the NTFs. Alternatively, the reduced number of regrown neurites may reflect that the NTFs have fewer surviving SGCs to affect. Taken together, the combination of BDNF $+\mathrm{FGF}_{1}$ was effective, even when deafness-induced degeneration had reduced the normal SGC population by more than $40 \%$ after 6 weeks of deafness. These results have significant clinical implications, suggesting that even with delayed intervention, NTFs delivered at the time of implant will preserve SGCs in the cochlea and initiate regrowth of peripheral processes.

\section{Maintenance Versus Regrowth}

A small number of pan-Trk-immunolabeled SGC fibers were present in many control animals in which AP delivery was initiated 4 days postdeafening and assessment was 40 days following deafening. This suggests that a small percentage of SGC peripheral processes have a slower rate of degeneration, just as SGCs degenerate at different rates. It is possible that some small portion of the increased number of pan-Trk-immunolabeled fibers seen with BDNF and $\mathrm{FGF}_{1}$ treatment could reflect maintenance of remaining peripheral processes, not just induced regrowth. There were few pan-Trk-immunolabeled fibers in the control group with longer delays and assessment at longer times after deafness. This suggests 
that peripheral processes no longer remain at these later times and that increases predominantly reflect regrowth.

\section{Delayed NTF Treatment and SGC Survival}

The current SGC density data indicate that BDNF/ $\mathrm{FGF}_{1}$ treatment is as efficacious as $\mathrm{BDNF} / \mathrm{CNTF}_{\mathrm{AX} 1}$ is in preventing deafferentation-induced cell death. With a 2-week delay in treatment, both $\mathrm{BDNF} / \mathrm{CNTF}_{\mathrm{AX} 1}$ (Yamagata et al., 2004) and $\mathrm{BDNF} / \mathrm{FGF}_{1}$ treatments enhanced SGC density by approximately $3: 1$. Even with a 6-week delay in treatment, both $\mathrm{BDNF} / \mathrm{CNTF}_{\mathrm{AX} 1}$ (Yamagata et al., 2004) and $\mathrm{BDNF} / \mathrm{FGF}_{1}$ treatments enhanced SGC density by approximately 2:1. Although in this study we found greater SGC density after BDNF/ FGF treatment $\left(11-12\right.$ cells $\left./ 10,000 \mu^{2}\right)$ than after BDNF/CNTF treatment $\left(3-5\right.$ cells $\left./ 10,000 \mu \mathrm{m}^{2}\right)$, SGC density ratios for treated and untreated ears were similar, as we observed greater cell density in control tissues relative to that reported by Yamagata et al. (2004). Differences in cell survival in deafened control animals found in different investigations may reflect variation in the specific deafening protocol used (kanamycin/ethacrynic acid or $10 \%$ neomycin injected into the middle ear). As illustrated in Figure 4, "surviving" SGCs in AP-treated control animals were not completely normal in appearance, with some vacuolization, mitochondrial clumping, and nuclear displacement. These cells might not then be capable of normal function. Taken together, the data clearly demonstrate that although earlier treatment is superior, reliable increases in measures of cell survival can be observed even after a 6-week delay in treatment with either $\mathrm{BDNF} / \mathrm{FGF}_{1}$ or $\mathrm{BDNF} / \mathrm{CNTF}_{\mathrm{Ax} 1}$.

\section{Increase in SGCs: Could There Be Endogenous Populations of Precursor Cells?}

In normal ears, average SGC density was $9.49( \pm 0.6)$ cells $/ 10,000 \mu^{2}$ (see dashed line in Fig. 5). However, interestingly, in tissues from animals treated 4 days postdeafening, mean SGC density was 11.8 ( \pm 0.4$)$ cells/ $10,000 \mu \mathrm{m}^{2}$. Similarly, in tissues from animals treated 3 weeks postdeafening, mean SGC density was 10.9 ( \pm 0.8 ) cells $/ 10,000 \mu^{2}$. The observed increased SGC density in NTF-treated ears was statistically significant $(P<0.01)$. One possible explanation for this increased SGC density is that NTFs induced conversion of endogenous precursor or stem cells into neurons and thus greater cell density than that seen in tissues from normal animals. Indeed, there is now evidence that human and guinea pig AN both have the potential for self-renewal. Rask-Andersen et al. (2005) demonstrated that progenitor/stem cells removed to culture from human modiolus divide, multiply, and form neurospheres that then spin off individual cells that differentiate into mature neurons (expressing TrkB and TrkC receptors) or glial cells. They report that this process and the neurite growth observed in mature neurons are enhanced by NTFs. Such pluripotential cells have also been generated from whole cochlea and vestibular tissue from mice ( $\mathrm{Li}$ et al., 2003) . An alternative interpretation is that deafness induces transdifferentiation of glia into new SGCs and that NTFs applied at or near the time of trauma cause dedifferentiation of SGCs to an earlier developmental state where they are capable of reentering the cell cycle, dividing, and differentiating into new (more) SGCs. The evidence supporting this dedifferentiation hypothesis includes the observation that spiral ganglion neurons evaluated after aminoglycoside treatment resemble gestational neurons (Dodson, 1997; Dodson and Mohuiddin, 2000). These may then provide a future mechanism for AN replacement, along with application of exogenous stem cells (Ito et al., 2001; Iguchi et al., 2003; Tamura et al., 2004; Hu et al., 2005;). The potential for clinical impact of increasing AN survival/ regrowth is clearly increased when these results are considered in combination with the demonstration of hair cell regeneration in guinea pigs (Izumikawa et al., 2005).

\section{Combinations of Treatments}

The benefits of combined treatment with NTFs and electrical stimulation were shown by Kanzaki et al. (2002), who induced expression of GDNF in the cochlea using viral vectors (delivered 5 days postdeafening) and initiated electrical stimulation 8 days postdeafening. Ears treated with GDNF (approximately 9 cells $/ 10,000 \mu^{2}$ ) had significantly greater SGC density than did electrically stimulated ears (approximately 7.5 cells $/ 10,000 \mu \mathrm{m}^{2}$ ); ears treated with a combination of GDNF + electrical stimulation (approximately 10.5 cells $/ 10,000 \mu^{2}$ ) had significantly greater SGC density than that of ears treated with either GDNF or electrical stimulation alone. That the factors were additive indicates that GDNF and electrical stimulation exert their protective effects through separate biochemical pathways; however, because the concentration of GDNF delivered cannot be specified or demonstrated to be optimal, mechanistic interpretation of these findings must be made cautiously. Because the combination of $\mathrm{BDNF}+\mathrm{FGF}_{1}$ described in this study (approximately 11 cells $/ 10,000 \mu^{2}$ ) was more efficacious in supporting SGC survival than was GDNF in the studies of Kanzaki et al. (2002) and others $\left(627-877\right.$ cells $/ 10,000 \mathrm{~mm}^{2}$; Ylikoski et al., 1998), these results suggest BDNF $+\mathrm{FGF}_{1}+$ electrical stimulation may better enhance SGC survival than other NTF + electrical stimulation combinations.

As reviewed by Gillespie et al. (2003), BDNF treatment can increase nitric oxide synthase (NOS) and nitric oxide (NO) production. Combination therapy that includes NTFs and either NOS inhibitors or free-radical scavengers (that bind to NO) might therefore be advantageous. For example, some interventions use antioxidants to reduce ROS associated with neurotrophin deprivation (see Satoh et al., 1999; Yamagata et al., 1999). Similar interventions are likely to be successful in the auditory system: whereas application of BDNF decreased cisplatin-induced ROS and improved survival, withdrawal of BDNF increased ROS in auditory neurons (Gabaizadeh et al., 1997). Like NTFs, free-radical scavengers can be delivered directly into the cochlea, using viral vectors, for example Kawamoto et al., 2004. These 
agents can also be delivered locally in the cochlea, and both systemic and local delivery of a combination of vitamin $\mathrm{C}$ (ascorbic acid) and vitamin E (trolox) have been shown to effectively increase SGC density and preserve auditory function (assessed as eABR threshold) following deafening via local intracochlear injection of the aminoglycoside neomycin (Maruyama et al., 2007). As described above for other NTF combinations, delivering both GDNF and vitamins C and E protected auditory thresholds significantly better than did GDNF alone (Maruyama et al., 2003). Therapies that include antioxidant agents may have the additional benefit of acting to preserve not only neural populations, but also hair cells (for a review, see Le Prell et al., 2007b).

\section{Clinical Trials for Translation to Humans}

Clinical trials with neurotrophic factors have in the past been challenging because of the short in vivo halflife of NTFs, as well as poor pharmacokinetics, proteolytic degradation, and inability of these large polypeptides to cross the blood-brain barrier when delivered systemically (for a review, see Saragovi and Gehring, 2000). However, recent improvements in drug delivery techniques, including, for example, gene therapy, stem-cell therapy, microencapsulation of neurotrophins (or genetically engineered cells that secret neurotrophins), and design of small-molecule neurotrophin mimetics, all provide potential solutions (for a review, see Saragovi and Gehring, 2000). Moreover, in the case of the impaired inner ear, neurotrophic agents can be delivered directly into the cochlea during implant procedures, thus reducing potential blood-brain barrier issues and attaining relatively high concentrations with restricted systemic side effects. Because many nutritional supplements (i.e., vitamins $\mathrm{A}, \mathrm{C}$, and $\mathrm{E}$ ) are potent free-radical scavengers that can be consumed orally with no adverse side effects when taken at recommended doses, the potential for combination therapeutics in humans is clear.

\section{CONCLUSIONS}

This study is the first in vivo demonstration that SGCs are capable of regrowing their peripheral processes following degeneration. Moreover, regrowth is possible in a population that has sufficiently advanced toward cell death that more than $40 \%$ of the SGCs have been destroyed. If the NTF intervention initiates neurite growth in endogenous neurons, it may be that such an intervention may also be used to stimulate neurite growth in exogenous (stem) cell implants, enabling integration of implants into the central pathways. A regrowth of excitable processes in the implanted ear may enhance integration of an implant with the nervous system, reducing battery requirements, increasing frequency separation, and allowing more channels of information and superior benefits to patients receiving cochlear implants. These findings provide a basis for future studies that will examine if the regrowth can be directed toward specific sites on a prosthesis.
As the criteria for implanting human patients with cochlear prostheses are expanded (National Institutes of Health, 1995), patients with greater residual hearing (and thus greater residual populations of apical hair cells and neurons) are receiving intracochlear devices. By combining implant procedures that minimize surgical trauma (to retain these residual populations of apical hair cells and neurons; e.g., Lehnhardt, 1993; Cohen, 1997) and delivering NTFs to stimulate neural proliferation toward the prosthesis, cochlear implant function and the corresponding "acoustic" sensation are likely to significantly improve. Consistent with this prediction, Gantz et al. implanted shorter (10-mm) intracochlear electrode arrays that preserve intact low-frequency hearing. Electrical stimulation of the base of the cochlea combined with acoustic stimulation of the intact apical cochlea (via hearing aid use) enhanced perceptual experience for cochlear implant users (Gantz et al., 2000; 2004; Tyler et al., 2000; Gantz and Turner 2003; Turner et al., 2004). Similar results were described in a case study by Skarzynski et al. (2003). Recent data from Le Prell et al. (2006) document the potential for electrical stimulation of intact/remaining hair cell populations to produce tonelike auditory sensations with electrical stimulation of the cochlea. With the potential that one day we will be able to induce hair cell regeneration in humans, such as that which has now been done in guinea pigs (Izumikawa et al., 2005), the potential for interventions that increase neural survival are ever more important. The addition of free-radical scavengers to the treatment regimen is likely to further improve clinical outcome given the positive effects on both hair cell and neural survival (Le Prell et al., 2007a; Maruyama et al., 2007). Taken together, the ability to preserve and induce regrowth of AN fibers is a key clinical outcome that will be increasingly important as mechanisms of hair cell preservation and regeneration continue to improve.

\section{ACKNOWLEDGMENTS}

These results were presented in abstract form at the 26th midwinter meeting of the Association for Research in Otolaryngology (Miller et al., 2003). Support for this research was provided by the AMGEN Corporation, which generously provided the BDNF, as well as by the National Institutes of Health (NIH-NIDCD R01 DC03820 and P30 DC005188), the General Motors Corporation, and the Ruth and Lynn Townsend Professor of Communication Disorders. We are grateful to Alice Mitchell, Jong-Seung Kim, Soo Duk Lee, and Ling Tong for their technical assistance.

\section{REFERENCES}

Aletsee C, Brors D, Mlynski R, Ryan AF, Dazert S. 2003. Branching of spiral ganglion neurites is induced by focal application of fibroblast growth factor-1. Laryngoscope 113:791-796.

Altschuler RA, Cho Y, Ylikoski J, Pirvola U, Magal E, Miller JM. 1999. Rescue and regrowth of sensory nerves following deafferentation by neurotrophic factors. Ann N Y Acad Sci 884:305-311. 
Brown JN, Miller JM, Altschuler RA, Nuttall AL. 1993. Osmotic pump implant for chronic infusion of drugs into the inner ear. Hear Res 70(2):167-172.

Chong ZZ, Kang JQ, Maiese K. 2004. Essential cellular regulatory elements of oxidative stress in early and late phases of apoptosis in the central nervous system. Antioxid Redox Signal 6:277-287.

Clopton BM, Spelman FA, Miller JM. 1980. Estimates of essential neural elements for stimulation through a cochlear prosthesis. Ann Otol Rhinol Laryngol Suppl 89(2 Pt 2):5-7.

Cohen NL. 1997. Cochlear implant soft surgery: fact or fantasy? Otolaryngol Head Neck Surg 117(3 Pt 1):214-216.

Dazert S, Kim D, Luo L, Aletsee C, Garfunkel S, Maciag T, Baird A, Ryan AF. 1998. Focal delivery of fibroblast growth factor-1 by transfected cells induces spiral ganglion neurite targeting in vitro. J Cell Physiol 177(1):123-129.

de la Monte SM, Neely TR, Cannon J, Wands JR. 2000. Oxidative stress and hypoxia-like injury cause Alzheimer-type molecular abnormalities in central nervous system neurons. Cell Mol Life Sci 57:1471-1481.

Dodson HC. 1997. Loss and survival of spiral ganglion neurons in the guinea pig after intracochlear perfusion with aminoglycosides. J Neurocytol 26:541-556.

Dodson HC, Mohuiddin A. 2000. Response of spiral ganglion neurones to cochlear hair cell destruction in the guinea pig. J Neurocytol 29:525-537.

Ernfors P, Duan ML, ElShamy WM, Canlon B. 1996. Protection of auditory neurons from aminoglycoside toxicity by neurotrophin-3. Nat Med 2:463-467.

Firszt JB, Holden LK, Skinner MW, Tobey EA, Peterson A, Gaggl W, Runge-Samuelson CL, Wackym PA. 2004. Recognition of speech presented at soft to loud levels by adult cochlear implant recipients of three cochlear implant systems. Ear Hear 25:375-387.

Gabaizadeh R, Staecker H, Liu W, Van De Water TR. 1997. BDNF protection of auditory neurons from cisplatin involves changes in intracellular levels of both reactive oxygen species and glutathione. Brain Res Mol Brain Res 50(1-2):71-78.

Gantz BJ, Rubinstein JT, Tyler RS, Teagle HF, Cohen NL, Waltzman SB, Miyamoto RT, Kirk KI. 2000. Long-term results of cochlear implants in children with residual hearing. Ann Otol Rhinol Laryngol Suppl 185:33-36.

Gantz BJ, Turner C. 2004. Combining acoustic and electrical speech processing: Iowa/Nucleus hybrid implant. Acta Otolaryngol 124:344-347.

Gantz BJ, Turner CW. 2003. Combining acoustic and electrical hearing. Laryngoscope 113:1726-1730.

Gilgun-Sherki Y, Melamed E, Offen D. 2003. Antioxidant treatment in Alzheimer's disease: current state. J Mol Neurosci 21(1):1-11.

Gillespie LN, Clark GM, Bartlett PF, Marzella PL. 2001. LIF is more potent than BDNF in promoting neurite outgrowth of mammalian auditory neurons in vitro. Neuroreport 12(2):275-279.

Gillespie LN, Clark GM, Bartlett PF, Marzella PL. 2003. BDNF-induced survival of auditory neurons in vivo: Cessation of treatment leads to accelerated loss of survival effects. J Neurosci Res 71:785-790.

Gillespie LN, Clark GM, Marzella PL. 2004. Delayed neurotrophin treatment supports auditory neuron survival in deaf guinea pigs. Neuroreport 15:1121-1125.

Hartnick CJ, Staecker H, Malgrange B, Lefebvre PP, Liu W, Moonen G, Van De Water TR. 1996. Neurotrophic effects of BDNF and CNTF, alone and in combination, on postnatal day 5 rat acoustic ganglion neurons. J Neurobiol 30(2):246-254.

Hossain WA, Morest DK. 2000. Fibroblast growth factors (FGF-1, FGF-2) promote migration and neurite growth of mouse cochlear ganglion cells in vitro: immunohistochemistry and antibody perturbation. J Neurosci Res 62(1):40-55.

Hu Z, Wei D, Johansson CB, Holmstrom N, Duan M, Frisen J, Ulfendahl M. 2005. Survival and neural differentiation of adult neural stem cells transplanted into the mature inner ear. Exp Cell Res 302(1):40-47.
Iguchi F, Nakagawa T, Tateya I, Kim TS, Endo T, Taniguchi Z, Naito Y, Ito J. 2003. Trophic support of mouse inner ear by neural stem cell transplantation. Neuroreport 14(1):77-80.

Incesulu A, Nadol JB Jr. 1998. Correlation of acoustic threshold measures and spiral ganglion cell survival in severe to profound sensorineural hearing loss: implications for cochlear implantation. Ann Otol Rhinol Laryngol 107:906-911.

Ito J, Kojima K, Kawaguchi S. 2001. Survival of neural stem cells in the cochlea. Acta Otolaryngol 121(2):140-142.

Izumikawa M, Minoda R, Kawamoto K, Abrashkin KA, Swiderski DL, Dolan DF, Brough DE, Raphael Y. 2005. Auditory hair cell replacement and hearing improvement by Atoh1 gene therapy in deaf mammals. Nat Med 11:271-276.

Jyung RW, Miller JM, Cannon SC. 1989. Evaluation of eighth nerve integrity by the electrically evoked middle latency response. Otolaryngol Head Neck Surg 101:670-682.

Kanzaki S, Stover T, Kawamoto K, Prieskorn DM, Altschuler RA, Miller JM, Raphael Y. 2002. Glial cell line-derived neurotrophic factor and chronic electrical stimulation prevent VIII cranial nerve degeneration following denervation. J Comp Neurol 454:350-360.

Kawamoto K, Sha SH, Minoda R, Izumikawa M, Kuriyama H, Schacht J, Raphael Y. 2004. Antioxidant gene therapy can protect hearing and hair cells from ototoxicity. Mol Ther 9(2):173-181.

Kirkland RA, Franklin JL. 2003. Bax, reactive oxygen, and cytochrome c release in neuronal apoptosis. Antioxid Redox Signal 5:589-596.

Konishi T, Kelsey E. 1973. Effect of potassium deficiency on cochlear potentials and cation contents of the endolymph. Acta Otolaryngol 76:410-418.

Lalwani AK, Han JJ, Castelein CM, Carvalho GJ, Mhatre AN. 2002. In vitro and in vivo assessment of the ability of adeno-associated virusbrain-derived neurotrophic factor to enhance spiral ganglion cell survival following ototoxic insult. Laryngoscope 112:1325-1334.

Le HN, Frim DM. 2002. Gene therapy for Parkinson's disease. Expert Opin Biol Ther 2(2):151-161.

Le Prell CG, Hughes LF, Miller JM. 2007a. Free radical scavengers, vitamins $\mathrm{A}, \mathrm{C}$, and $\mathrm{E}$, plus magnesium reduces noise trauma. Free Rad Biol Med 42:1454-1463.

Le Prell CG, Kawamoto K, Raphael Y, Dolan DF. 2006. Electromotile hearing: Acoustic tones mask psychophysical response to high-frequency electrical stimulation of intact guinea pig cochleae. J Acoust Soc Am 120:3889-3900.

Le Prell CG, Yagi M, Kawamoto K, Beyer LA, Atkin G, Raphael Y, Dolan D, Bledsoe SC Jr, Moody DB. 2004. Chronic excitotoxicity in the guinea pig cochlea induces temporary functional deficits and longterm morphological trauma. J Acoust Soc Am 116:1044-1056.

Le Prell CG, Yamashita D, Minami S, Yamasoba T, Miller JM. 2007b. Mechanisms of noise-induced hearing loss indicate multiple methods of prevention. Hear Res 226(1-2):22-43.

Lefebvre PP, Malgrange B, Staecker H, Moghadass M, Van De Water TR, Moonen G. 1994. Neurotrophins affect survival and neuritogenesis by adult injured auditory neurons in vitro. Neuroreport 5:865-868.

Lehnhardt E. 1993. [Intracochlear placement of cochlear implant electrodes in soft surgery technique]. HNO 41:356-359.

Lewen A, Matz P, Chan PH. 2000. Free radical pathways in CNS injury. J Neurotrauma 17:871-890.

Li H, Liu H, Heller S. 2003. Pluripotent stem cells from the adult mouse inner ear. Nat Med 9:1293-1299.

Malgrange B, Lefebvre P, Van De Water TR, Staecker H, Moonen G. 1996. Effects of neurotrophins on early auditory neurones in cell culture. Neuroreport 7:913-917.

Maruyama J, Mannström P, Bredberg G, Miller JM, Ulfendahl M. 2003. Effects of combination treatment with antioxidants and GDNF on auditory function in deafened guinea pigs. Abs Assoc Res Otolaryngol 26:195.

Maruyama J, Yamagata T, Ulfendahl M, Bredberg G, Altschuler RA, Miller JM. 2007. Effects of antioxidants on auditory nerve function and survival in deafened guinea pigs. Neurobiol Dis 25:309-318. 
Mattson MP. 1998. Neuroprotective strategies based on targeting of postrecptor signaling events. In: Mattson MP, editor. Neuroprotective signal transduction. Totowa, NJ: Humana Press. p 301-335,345.

Mattson MP, Scheff SW. 1994. Endogenous neuroprotection factors and traumatic brain injury: mechanisms of action and implications for therapy. J Neurotrauma 11(1):3-33.

McFadden SL, Ding D, Jiang H, Salvi RJ. 2004. Time course of efferent fiber and spiral ganglion cell degeneration following complete hair cell loss in the chinchilla. Brain Res 997(1):40-51.

Miller JM, Chi DH, O'Keeffe LJ, Kruszka P, Raphael Y, Altschuler RA. 1997. Neurotrophins can enhance spiral ganglion cell survival after inner hair cell loss. Int J Dev Neurosci 15:631-643.

Miller JM, Prieskorn DM, Wys NL, Altschuler RA. 2003. Delayed neurotrophin treatment following deafness rescues spiral ganglion cells from death and promotes regrowth of auditory nerve peripheral processes. Abs Assoc Res Otolaryngol 26:248-249.

Mou K, Hunsberger CL, Cleary JM, Davis RL. 1997. Synergistic effects of BDNF and NT-3 on postnatal spiral ganglion neurons. J Comp Neurol 386:529-539.

Nadol JB Jr, Young YS, Glynn RJ. 1989. Survival of spiral ganglion cells in profound sensorineural hearing loss: implications for cochlear implantation. Ann Otol Rhinol Laryngol 98:411-416.

Nakaizumi T, Kawamoto K, Minoda R, Raphael Y. 2004. Adenovirusmediated expression of brain-derived neurotrophic factor protects spiral ganglion neurons from ototoxic damage. Audiol Neurootol 9(3):135-143.

National Institutes of Health, 1995. Cochlear implants in adults and children. NIH Consens Statement 13(2):1-30.

Pflug BR, Dionne C, Kaplan DR, Lynch J, Djakiew D. 1995. Expression of a Trk high affinity nerve growth factor receptor in the human prostate. Endocrinology 136(1):262-268.

Prieskorn DM, Miller JM. 2000. Technical report: chronic and acute intracochlear infusion in rodents. Hear Res 140(1-2):212-215.

Puel JL, Saffiedine S, Gervais d'Aldin C, Eybalin M, Pujol R. 1995. Synaptic regeneration and functional recovery after excitotoxic injury in the guinea pig cochlea. C R Acad Sci III 318(1):67-75.

Rask-Andersen H, Bostrom M, Gerdin B, Kinnefors A, Nyberg G, Engstrand T, Miller JM, Lindholm D. 2005. Regeneration of human auditory nerve. In vitro/in video demonstration of neural progenitor cells in adult human and guinea pig spiral ganglion. Hear Res 203:180-191.

Rask-Andersen H, Ekvall L, Scholtz A, Schrott-Fischer A. 2000. Structural/audiometric correlations in a human inner ear with noise-induced hearing loss. Hear Res 141(1-2):129-139.

Saragovi HU, Gehring K. 2000. Development of pharmacological agents for targeting neurotrophins and their receptors. Trends Pharmacol Sci 21(3):93-98.

Satoh T, Yamagata T, Ishikawa Y, Yamada M, Uchiyama Y, Hatanaka H. 1999. Regulation of reactive oxygen species by nerve growth factor but not Bcl-2 as a novel mechanism of protection of PC12 cells from superoxide anion-induced death. J Biochem (Tokyo) 125:952-959.

Schindler RA, Gladstone HB, Scott N, Hradek GT, Williams H, Shah SB. 1995. Enhanced preservation of the auditory nerve following cochlear perfusion with nerve growth factors. Am J Otol 16:304-309.

Shah SB, Gladstone HB, Williams H, Hradek GT, Schindler RA. 1995. An extended study: protective effects of nerve growth factor in neomycininduced auditory neural degeneration. Am J Otol 16:310-314.

Shinohara T, Bredberg G, Ulfendahl M, Pyykko I, Olivius NP, Kaksonen R, Lindstrom B, Altschuler R, Miller JM. 2002. Neurotrophic factor intervention restores auditory function in deafened animals. Proc Natl Acad Sci U S A 99:1657-1660.

Shoji F, Yamasoba T, Magal E, Dolan DF, Altschuler RA, Miller JM. 2000. Glial cell line-derived neurotrophic factor has a dose dependent influence on noiseinduced hearing loss in the guinea pig cochlea. Hear Res 142(1-2):41-55.

Skarzynski H, Lorens A, Piotrowska A. 2003. A new method of partial deafness treatment. Med Sci Monit 9(4):CS20-CS24.
Skinner MW, Clark GM, Whitford LA, Seligman PM, Staller SJ, Shipp DB, Shallop JK, Everingham C, Menapace CM, Arndt PL, et al., 1994. Evaluation of a new spectral peak coding strategy for the Nucleus 22 Channel Cochlear Implant System. Am J Otol 15(Suppl 2):15-27.

Skinner MW, Holden LK, Holden TA, Demorest ME, Fourakis MS. 1997. Speech recognition at simulated soft, conversational, and raisedto-loud vocal efforts by adults with cochlear implants. J Acoust Soc Am 101:3766-3782.

Skinner MW, Ketten DR, Holden LK, Harding GW, Smith PG, Gates GA, Neely JG, Kletzker GR, Brunsden B, Blocker B. 2002. CTderived estimation of cochlear morphology and electrode array position in relation to word recognition in Nucleus-22 recipients. J Assoc Res Otolaryngol 3:332-350.

Spoendlin H. 1971. Primary structural changes in the organ of Corti after acoustic overstimulation. Acta Otolaryngol 71(2):166-176.

Spoendlin H, Brun JP. 1973. Relation of structural damage to exposure time and intensity in acoustic trauma. Acta Otolaryngol 75(2):220-226.

Staecker H, Galinovic-Schwartz V, Liu W, Lefebvre P, Kopke R, Malgrange B, Moonen G, Van De Water TR. 1996a. The role of the neurotrophins in maturation and maintenance of postnatal auditory innervation. Am J Otol 17:486-492.

Staecker H, Kopke R, Malgrange B, Lefebvre P, Van De Water TR. 1996b. NT-3 and/or BDNF therapy prevents loss of auditory neurons following loss of hair cells. Neuroreport 7:889-894.

Summers WK. 2004. Alzheimer's disease, oxidative injury, and cytokines. J Alzheimers Dis 6:651-657; discussion 673-681.

Tamura T, Nakagawa T, Iguchi F, Tateya I, Endo T, Kim TS, Dong Y, Kita T, Kojima K, Naito Y, Omori K, Ito J. 2004. Transplantation of neural stem cells into the modiolus of mouse cochleae injured by cisplatin. Acta Otolaryngol Suppl 551:65-68.

Tenenbaum L, Chtarto A, Lehtonen E, Blum D, Baekelandt V, Velu T, Brotchi J, Levivier M. 2002. Neuroprotective gene therapy for Parkinson's disease. Curr Gene Ther 2:451-483.

Thomas M, Le WD. 2004. Minocycline: neuroprotective mechanisms in Parkinson's disease. Curr Pharm Des 10:679-686.

Turner CW, Gantz BJ, Vidal C, Behrens A, Henry BA. 2004. Speech recognition in noise for cochlear implant listeners: benefits of residual acoustic hearing. J Acoust Soc Am 115:1729-1735.

Tyler RS, Kelsay DM, Teagle HF, Rubinstein JT, Gantz BJ, Christ AM. 2000. 7-year speech perception results and the effects of age, residual hearing and preimplant speech perception in prelingually deaf children using the Nucleus and Clarion cochlear implants. Adv Otorhinolaryngol 57:305-310

Waltzman SB, Cohen NL, Gomolin RH, Green JE, Shapiro WH, Hoffman RA, Roland JT Jr. 1997. Open-set speech perception in congenitally deaf children using cochlear implants. Am J Otol 18:342-349.

Webster M, Webster DB. 1981. Spiral ganglion neuron loss following organ of Corti loss: a quantitative study. Brain Res 212(1):17-30.

West BA, Brummett RE, Himes DL. 1973. Interaction of kanamycin and ethacrynic acid. Severe cochlear damage in guinea pigs. Arch Otolaryngol 98(1):32-37.

Yamagata T, Miller JM, Ulfendahl M, Olivius NP, Altschuler RA, Pyykko I, Bredberg G. 2004. Delayed neurotrophic treatment preserves nerve survival and electrophysiological responsiveness in neomycindeafened guinea pigs. J Neurosci Res 78(1):75-86.

Yamagata T, Satoh T, Ishikawa Y, Nakatani A, Yamada M, Ikeuchi T, Hatanaka H. 1999. Brain-derived neurotropic factor prevents superoxide anion-induced death of PC12h cells stably expressing TrkB receptor via modulation of reactive oxygen species. Neurosci Res 35(1):9-17.

Ylikoski J, Pirvola U, Virkkala J, Suvanto P, Liang XQ, Magal E, Altschuler R, Miller JM, Saarma M. 1998. Guinea pig auditory neurons are protected by glial cell line-derived growth factor from degeneration after noise trauma. Hear Res 124(1-2):17-26. 